\title{
A nationwide survey of psychological distress among Indonesian residents during the COVID-19 pandemic
}

\author{
Titik Respati ${ }^{1}$, Siska Nia Irasanti ${ }^{2}$, Dewi Sartika ${ }^{3}$, Ieva B. Akbar ${ }^{4}$, Roy Rillera Marzo ${ }^{5}$ \\ ${ }^{1,2,4}$ Faculty of Medicine, Universitas Islam Bandung, Indonesia \\ ${ }^{3}$ Faculty of Psychology, Universitas Islam Bandung, Indonesia \\ ${ }^{5}$ Faculty of Medicine, Asia Metropolitan University, Malaysia
}

\begin{tabular}{l} 
Article Info \\
\hline Article history: \\
Received Aug 6, 2020 \\
Revised Dec 20, 2020 \\
Accepted Jan 4, 2021 \\
\hline
\end{tabular}

\section{Keywords:}

Age

COVID-19

Mental health

Psychological intervention

Stress

\begin{abstract}
The Coronavirus disease (COVID-19) has become a public health emergency. The speed at which COVID-19 become pandemic and spread all over the world is alarming. A critical aspect of this type of pandemic is on the mental health of the community. This survey aimed to describe psychological distress in Indonesia's general population during the COVID19 pandemic. Data collection began on 1st April 2020 to 30th April 2020. An online survey using Google Form with snowball sampling method used in this study. A modified version of the COVID-19 peri-traumatic distress index (CPDI) with 24 items used. The survey questionnaire included socioeconomic and demographic variables. The study's total responses were 1,287, with 33 excluded from the analysis because of incomplete responses or not meeting inclusion criteria. Results showed that $63.5 \%$ of respondents reported having normal or no distress, $34 \%$ were having mild to moderate levels of distress, and $2.8 \%$ having severe distress. Age is the only variable that correlates with the level of distress. Healthcare workers and the general population showed no significant differences in the level of distress. During the early break of the COVID-19 pandemic, around $40 \%$ of respondents rated their psychological state having moderate to severe distress. These findings can be used to develop better psychological intervention measures and prevention of mental health during the pandemic.
\end{abstract}

This is an open access article under the CC BY-SA license.

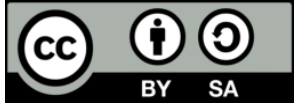

\section{Corresponding Author:}

Titik Respati

Faculty of Medicine

Universitas Islam Bandung

Jl. Tamansari 22 Bandung 40116, Indonesia

Email: titik.respati@gmail.com

\section{INTRODUCTION}

On the 1st August 2020, COVID-19 cases reached 17,780,342 cases worldwide, with 683,463 casualties, while Indonesia recorded 109,936 cases with 5,193 death [1]. Since the virus found in Wuhan, China, in late 2019, cases of COVID-19 found in almost all countries in the world except several Pacific Island countries. World Health Organization claimed it as the public health emergency [2]. The coronavirus's spread took us all by surprise, and the speed at which it has spread all over the world is alarming. There is almost no country immune from the impact caused by this virus. It is not only the impact on health issues but also the economy and political issues [3]. Some studies stated that vulnerable groups such as older people, women, children, people with comorbid such as diabetes melitus, autoimmune diseases and health workers were some group that need special attention [4-8]. 
The prevention for this outbreak is by physical distancing and wearing personal protection equipment such ask face masks which also comes with its own problems of medical wastes [9, 10]. Other than impact on biology and physical condition, mental health issues become challenging in this pandemic era $[11,12]$. World Health Organization stated that managing mental health for the whole family during a pandemic is very important [13]. Articles in the newspapers and research address many problems related to mental health during COVID-19 in different groups and communities in several countries [7, 11, 14-16]. The Indonesian government has already developed some guidance related to the prevention of COVID-19, including some new normal guidance and for psychological issues [17-20]. The approach of lockdown that forces people to stay at home, work from home, and school from home increases the level of stress among family members [21-23]. Some concern regarding the use of internet which has advantages and disadvantages on family life [24]. Research showed that the COVID-19 pandemic could be suppressed by a lockdown although there are also some disadvantages [25].

The stress compounding with a negative stigma on people with a mental health issue will develop to other problems [26, 27] Many kinds of research address mental health issues, and COVID-19 pandemic stated that, although the primary approach for physical distancing and personal hygiene is important, mental health issues need to be addressed more seriously [9]. Health workers, especially those who treat COVID-19 patients, need to be able to assess not only patients' mental health but also their conditions [7, 12, 28]. United nations already warned that mental health would become a global problem if not appropriately addressed. The community needs to understand the magnitude of the problem during the COVID-19 pandemic to ensure they followed every health protocol assigned. Several countries reported the increase in COVID-19 cases when the lockdown was open [15,29]. On the other and, it is quite challenging to maintain the restriction on the base of economic and social issues [3, 30, 31] It is important to address mental health issues in the community that the government and other parties can work together to develop tools and policies to prevent it. This survey aimed to describe psychological distress in Indonesia's general population during the COVID19 pandemic that can be used for policy recommendations.

\section{RESEARCH METHOD}

In Indonesia, data collection began on 1st April 2020, around two weeks when lockdown enforced on 20th March 2020, and ends on 30th April 2020. Online survey using Google Form with snowball sampling method used with the request sent through social media such as WhatsApp groups to participate in this survey. All respondents gave their informed consent for inclusion before they participated in the study. The study was conducted in accordance with the protocol and approved by the Faculty of Medicine Universitas Islam Bandung Ethics Committee Number: 394/Komite Etik.FK/III/2020. A modified version of the COVID-19 peri-traumatic distress index (CPDI) with 24 items used [6]. The present study has used the Indonesian version of the CPDI, and internal consistency assessed using Cronbach's $\alpha$. The internal reliability of the present study found to be 0.887 , which shows reliability. For each of the 24 items, subjects asked to measure measures emotional impact related to COVID-19 and their frequency of the activities in the last week. The 5-point Likert scoring system used as follows: Never-0, Occasionally-1, Sometimes-2, Often3, Always-4. The Psychological distress defines by the total score. A total of the score of 0-28 consider normal, the total score between 29 and 51 indicates mild to moderate distress and a score of greater than and equal to 52 indicates severe distress.

The survey questionnaire included socio-economic and demographic variables such as age $(<30,30$ 45, 46-60 and 60 above), gender (female, male), Religion (Islam, Non-Islam), Education (Primary, Secondary and Tertiary), Occupation (employed, unemployed, and students), Income (<IDR 1,700,000, IDR 1,700,000-IDR 4,500,000 and >IDR 4,500,000), Place of residence (Java Island and Outside Java Island), and being health worker (Yes/No). A summary statistic was presented for independent as well as dependent variables to assess the distribution. Categorical variables were summarized using percentages. A Chi-square test was used to test for associations between two categorical variables. Hence this test is performed to see the association between distress which is categorical and background characteristics which is also categorical. There are a high proportion of women versus men; this is also reported in other experiences performed by web-based questionnaires related to COVID-19.

\section{RESULTS AND DISCUSSION}

The total responses in the study were 1,287. Five cases excluded from the study because they were not fulfilling the inclusion criteria (less than 18 years of age). Further 25 cases more were excluded from the analysis because of incomplete data of the COVID-19 distress tool. Table 1 presents the socio-economic profile of respondents participated in the study. 
Table 1 show that the minimum age of the respondents was 18 , and the maximum was 75 . About $44 \%$ of the participants were below 30 years old, and about two-thirds were female $(64 \%)$. About $89 \%$ of participants followed Islam religion, and more than three-fourth participants had a secondary level of education. About two-thirds of the participants were employed, and $47 \%$ of the respondents' family income was more than 4,500,000 Indonesian rupiah. About $81 \%$ of participants were the residence of Java Island, and $15 \%$ of respondents reported they were healthcare workers. Table 2 shows the topics on the CPDI and responses. Table 2 presents the prevalence of each symptom of CPDI, ranging from 10\% to $99 \%$. I feel sympathetic to COVID-19 patients, and their families (99\%) were the most common felt by respondents. It followed by feeling more nervous and anxious (86\%), and I cannot stop myself from imagining myself or my family being infected and feeling terrified and anxious about it (84\%). Prevalence of lowest distress reported for the item that stated I have frequent awakening at night due to my dream about myself or my family being infected by COVID-19 (10\%). Recently, I rarely talk to my family (32.5\%), and I am more irritable and have frequent conflicts with my family $(40.3 \%)$. Table 3 presented the descriptive and internal consistency of the CPDI.

Table 3 reveals that the psychiatric tool's internal consistency was high, with Cronbach's alpha of 0.887. Cronbach's Alpha value for the item set-values $>0.70$ is usually considered good. Internal consistency did not improve if an item deleted from the scale. The corrected item-total correlations ranged from 0.04 to 0.69. Values for an item-total correlation between 0 and 0.19 may indicate that the question is not discriminating well. Values between 0.2 and 0.39 indicate good discrimination and values 0.4 and above indicate very good discrimination. A receiver operator characteristic (ROC) curve analysis performed to choose the cut-off for modified CPDI ( 24 items). The best cut-off has the highest true positive rate, together with the lowest false positive rate. The present study cut-off identified as $\leq 28$, and the area under the curve is 0.61 .9 with a $95 \%$ confidence interval $(.574,664)$. The area under the curve is significantly different from 0.5 since the p-value is 0.000 , meaning that the logistic regression classifies the group significantly better than chance. Table 4 described the prevalence of CPDI by socioeconomic and demographic status of respondents. receiver operator characteristic (ROC) curve as shown in Figure 1, internal consistency as shown in Table 5.

Table 1. Socio-demographic profile of the respondents $(n=1,257)$

\begin{tabular}{cccc}
\hline Variables & & Frequency & Percent \\
\hline Age & 300 & 557 & 44.3 \\
& $31-45$ & 524 & 41.7 \\
Gender & 46 and above & 176 & 14.0 \\
& Female & 805 & 64.0 \\
Religion & Male & 452 & 36.0 \\
& Islam & 1122 & 89.3 \\
Education & Non-Islam & 135 & 10.7 \\
& Primary & 95 & 7.6 \\
& Secondary & 987 & 78.5 \\
Occupation & Tertiary & 175 & 13.9 \\
& Employed & 837 & 66.6 \\
Monthly Family Income* & Unemployed & 151 & 12.0 \\
& Student & 269 & 21.4 \\
& IDR 1,700,000,- & 309 & 24.6 \\
Health worker & IDR & 351 & 27.9 \\
& 1,700,000 - IDR 4,500,000 & 597 & 47.5 \\
Residence & >IDR 4,500,000,- & 189 & 15.0 \\
& Yes & 1068 & 85.0 \\
Nationality & No & 1022 & 81.3 \\
& Java Island & 235 & 18.7 \\
Total & Outside Java Island & 1252 & 99.6 \\
Family income based on the region lowest basic monthly salary [IDR 1,700,000] to the highest [IDR 4,500,000] \\
\hline
\end{tabular}

Table 4 represents the prevalence of normal, mild to moderate and severe distress of COVID-19. The analysis shows that only the age of the respondents and distress is significantly associated. However, the variables of gender, religion, education, occupation, monthly family income, residence, and health worker is not significant with distress in bivariate analysis.

Figure 2 presents the prevalence of distress. About $63.5 \%$ were under the normal category of CPDI and were no distress. However, $34 \%$ had mild to moderate levels of distress, and $2.8 \%$ were having severe distress. This cross-sectional survey with 1257 respondents showed that most respondents $(63.5 \%)$ have normal or no distress. This result might contribute to the time of data collection. With data collected during 
the early days of the pandemic, the disease's experience and knowledge not yet developed. The real mental health impact of COVID-19 may take weeks or months to become fully apparent [11]. However, $2.8 \%$ of respondents already showed severe distress. Although the number seems small, it is an indication that mental health problems need to address early in the management of the pandemic responses. As some international organizations stated the importance of keeping mental health during this pandemic era, the Indonesian government also needs to address it [7, 20, 26].

Table 2. The presence of COVID19 peri-traumatic distress [CPDI] symptoms

\begin{tabular}{|c|c|c|c|c|c|}
\hline Topics & $\begin{array}{c}\text { Never } \\
\mathrm{n}[\%]\end{array}$ & $\begin{array}{c}\text { Occasionally } \\
\mathrm{n}[\%]\end{array}$ & $\begin{array}{l}\text { Sometimes } \\
\mathrm{n}[\%]\end{array}$ & $\begin{array}{l}\text { Often } \\
\mathrm{n}[\%]\end{array}$ & $\begin{array}{c}\text { Always } \\
\mathrm{n}[\%]\end{array}$ \\
\hline $\begin{array}{l}\text { Question 1: Compared to usual, I feel } \\
\text { more nervous and anxious }\end{array}$ & $169(13.4)$ & $261(20.8)$ & $637(50.7)$ & $178(14.2)$ & $12(1.0)$ \\
\hline $\begin{array}{l}\text { Question 2: I feel insecure and bought a } \\
\text { lot of masks, medications, sanitizers, } \\
\text { gloves and/or other home supplies. }\end{array}$ & $273(21.7)$ & $375(29.8)$ & $413(32.9)$ & $166(13.2)$ & $30(2.4)$ \\
\hline $\begin{array}{l}\text { Question 3: I cannot stop myself from } \\
\text { imagining myself or my family being } \\
\text { infected and feel terrified and anxious } \\
\text { about it. }\end{array}$ & $193(15.4)$ & $352(28.0)$ & $457(36.4)$ & $193(15.4)$ & $62(4.9)$ \\
\hline $\begin{array}{l}\text { Question 4: I feel helpless no matter } \\
\text { what I do. }\end{array}$ & $488(38.8)$ & $355(28.2)$ & $302(24.0)$ & $87(6.9)$ & $25(2.0)$ \\
\hline Question 5: I feel sympathetic to & $12(1.0)$ & $14(1.1)$ & $148(11.8)$ & $485(38.6)$ & $598(47.6)$ \\
\hline $\begin{array}{c}\text { COVID-19 patients and their families. } \\
\text { Question 6: I feel helpless and angry } \\
\text { about people around me, governors, and } \\
\text { media. }\end{array}$ & $417(33.2)$ & $332(26.4)$ & $382(30.4)$ & $108(8.6)$ & $18(1.4)$ \\
\hline $\begin{array}{l}\text { Question 7: I am losing faith in the } \\
\text { people around me. }\end{array}$ & $477(37.9)$ & $370(29.4)$ & $329(26.2)$ & $63(5.0)$ & $18(1.4)$ \\
\hline $\begin{array}{l}\text { Question 8: I collect information about } \\
\text { COVID-19 all day. Even if it's not } \\
\text { necessary, I can't stop myself. }\end{array}$ & $246(19.6)$ & $527(41.9)$ & $331(26.3)$ & $123(9.8)$ & $30(2.4)$ \\
\hline $\begin{array}{l}\text { Question 9: I will believe the COVID- } \\
19 \text { information from all sources without } \\
\text { any evaluation. }\end{array}$ & $437(34.8)$ & $510(40.6)$ & 243(19.3) & $44(3.5)$ & $23(1.8)$ \\
\hline $\begin{array}{l}\text { Question 10: I would rather believe in } \\
\text { negative news about COVID-19 and be } \\
\text { skeptical about the good news }\end{array}$ & $713(56.7)$ & $336(26.7)$ & 149(11.9) & $37(2.9)$ & $22(1.8)$ \\
\hline $\begin{array}{c}\text { Question 11: I am constantly sharing } \\
\text { news about COVID-19 (mostly } \\
\text { negative news]. }\end{array}$ & $662(52.7)$ & $435(34.6)$ & $125(9.9)$ & $28(2.2)$ & $7(0.6)$ \\
\hline $\begin{array}{l}\text { Question 13: I am more irritable and } \\
\text { have frequent conflicts with my family. }\end{array}$ & $503(40.0)$ & $318(25.3)$ & $310(24.7)$ & $98(7.8)$ & $28(2.2)$ \\
\hline $\begin{array}{l}\text { Question 13: I am more irritable and } \\
\text { have frequent conflicts with my family. }\end{array}$ & $750(59.7)$ & $319(25.4)$ & $135(10.7)$ & $48(3.8)$ & $5(0.4)$ \\
\hline $\begin{array}{l}\text { Question 14: I feel tired and sometimes } \\
\text { even exhausted. }\end{array}$ & $473(37.6)$ & $346(27.5)$ & $279(22.2)$ & 131(10.4) & $28(2.2)$ \\
\hline $\begin{array}{l}\text { Question } 15 \text { : When feelings anxious, } \\
\text { my reactions are becoming sluggish. }\end{array}$ & $531(42.2)$ & $374(29.8)$ & $258(20.5)$ & $79(6.3)$ & $15(1.2)$ \\
\hline $\begin{array}{l}\text { Question 16: I find it hard to } \\
\text { concentrate. }\end{array}$ & $526(41.8)$ & $355(28.2)$ & 247(19.6) & $110(8.8)$ & $19(1.5)$ \\
\hline $\begin{array}{c}\text { Question 17: I find it hard to make any } \\
\text { decisions. }\end{array}$ & $595(47.3)$ & $370(29.4)$ & $210(16.7)$ & $72(5.7)$ & $10(0.8)$ \\
\hline $\begin{array}{l}\text { Question 18: During this COVID-19 } \\
\text { period, I often feel dizzy or have back } \\
\text { pain and chest distress. }\end{array}$ & $659(52.4)$ & $304(24.2)$ & $217(17.3)$ & $68(5.4)$ & $9(0.7)$ \\
\hline $\begin{array}{l}\text { Question 19: During this COVID-19 } \\
\text { period, I often feel stomach pain, } \\
\text { bloating, and other stomach discomforts }\end{array}$ & $695(55.3)$ & $328(26.1)$ & $164(13.0)$ & $59(4.7)$ & $11(0.9)$ \\
\hline $\begin{array}{l}\text { Question 20: I feel uncomfortable when } \\
\text { communicating with others. }\end{array}$ & $371(29.5)$ & $369(29.4)$ & $379(30.2)$ & $120(95)$ & $18(1.4)$ \\
\hline $\begin{array}{l}\text { Question 21: Recently, I rarely talk to } \\
\text { my family. }\end{array}$ & $848(67.5)$ & $246(19.6)$ & $111(8.8)$ & $40(3.2)$ & $12(1.0)$ \\
\hline $\begin{array}{l}\text { Question 22: I have frequent awakening } \\
\text { at night due to my dream about myself } \\
\text { or my family being infected by } \\
\text { COVID- } 19 .\end{array}$ & $1126(89.6)$ & $92(7.3)$ & $28(2.2)$ & $10(0.8)$ & $1(0.1)$ \\
\hline $\begin{array}{c}\text { Question 23: I have changes in my } \\
\text { eating habits }\end{array}$ & $537(42.7)$ & $206(16.4)$ & $259(20.6)$ & $203(16.1)$ & $52(4.1)$ \\
\hline $\begin{array}{l}\text { Question 24: I have constipation or } \\
\text { frequent urination }\end{array}$ & $749(59.6)$ & $294(23.4)$ & $154(12.3)$ & $51(4.1)$ & $9(0.7)$ \\
\hline
\end{tabular}


Table 3. Descriptive statistics and internal consistency of COVID19 Peri-traumatic distress index

\begin{tabular}{|c|c|c|c|c|c|}
\hline & Mean & SD & $\begin{array}{l}\text { Corrected } \\
\text { item-total } \\
\text { correlation }\end{array}$ & $\begin{array}{c}\text { Cronbac } \\
\text { h's Alpha } \\
\text { if item } \\
\text { deleted }\end{array}$ & $\mathrm{n}$ \\
\hline Compared to usual, I feel more nervous and anxious. & 1.7 & 0.91 & 0.51 & 0.882 & 1257 \\
\hline $\begin{array}{c}\text { I feel insecure and bought a lot of masks, medications, sanitizers, gloves } \\
\text { and/or other home supplies. }\end{array}$ & 1.5 & 1.04 & 0.38 & 0.885 & 1257 \\
\hline $\begin{array}{c}\text { I can't stop myself from imagining myself or my family being infected } \\
\text { and feel terrified and anxious about it. }\end{array}$ & 1.7 & 1.07 & 0.53 & 0.881 & 1257 \\
\hline I feel helpless no matter what I do. & 1.1 & 1.04 & 0.61 & 0.879 & 1257 \\
\hline I feel sympathetic to COVID-19 patients and their families. & 3.3 & 0.79 & 0.04 & 0.892 & 1257 \\
\hline I feel helpless and angry about people around me, governors, and media. & 1.2 & 1.04 & 0.52 & 0.881 & 1257 \\
\hline I am losing faith in the people around me. & 1.0 & 0.99 & 0.51 & 0.881 & 1257 \\
\hline $\begin{array}{l}\text { I collect information about COVID-19 all day. Even if it's not necessary, } \\
\text { I can't stop myself. }\end{array}$ & 1.3 & 0.98 & 0.32 & 0.887 & 1257 \\
\hline $\begin{array}{l}\text { I will believe the COVID-19 information from all sources without any } \\
\text { evaluation. }\end{array}$ & 1.0 & 0.92 & 0.27 & 0.888 & 1257 \\
\hline $\begin{array}{l}\text { I would rather believe in negative news about COVID-19 and be } \\
\text { skeptical about the good news }\end{array}$ & 0.7 & 0.92 & 0.42 & 0.884 & 1257 \\
\hline I am constantly sharing news about COVID-19 (mostly negative news]. & 0.6 & 0.8 & 0.34 & 0.886 & 1257 \\
\hline I am more irritable and have frequent conflicts with my family. & 1.1 & 1.08 & 0.43 & 0.884 & 1257 \\
\hline I am more irritable and have frequent conflicts with my family. & 0.6 & 0.86 & 0.55 & 0.881 & 1257 \\
\hline I feel tired and sometimes even exhausted. & 1.1 & 1.1 & 0.60 & 0.879 & 1257 \\
\hline When feelings anxious, my reactions are becoming sluggish. & 0.9 & 0.99 & 0.65 & 0.878 & 1257 \\
\hline I find it hard to concentrate. & 1.0 & 1.05 & 0.67 & 0.877 & 1257 \\
\hline I find it hard to make any decisions. & 0.8 & 0.96 & 0.69 & 0.877 & 1257 \\
\hline $\begin{array}{c}\text { During this COVID-19 period, I often feel dizzy or have back pain and } \\
\text { chest distress. }\end{array}$ & 0.8 & 0.96 & 0.54 & 0.881 & 1257 \\
\hline $\begin{array}{c}\text { During this COVID-19 period, I often feel stomach pain, bloating, and } \\
\text { other stomach discomforts }\end{array}$ & 0.7 & 0.93 & 0.50 & 0.882 & 1257 \\
\hline I feel uncomfortable when communicating with others. & 1.2 & 1.03 & 0.48 & 0.882 & 1257 \\
\hline Recently, I rarely talk to my family. & 0.5 & 0.86 & 0.40 & 0.884 & 1257 \\
\hline $\begin{array}{l}\text { I have frequent awakening at night due to my dream about myself or my } \\
\text { family being infected by COVID-19. }\end{array}$ & 0.1 & 0.48 & 0.40 & 0.885 & 1257 \\
\hline I have changes in my eating habits & 1.2 & 1.27 & 0.43 & 0.885 & 1257 \\
\hline I have constipation or frequent urination & 0.6 & 0.9 & 0.43 & 0.884 & 1257 \\
\hline Total Score & 25.7 & 22.9 & & & \\
\hline
\end{tabular}

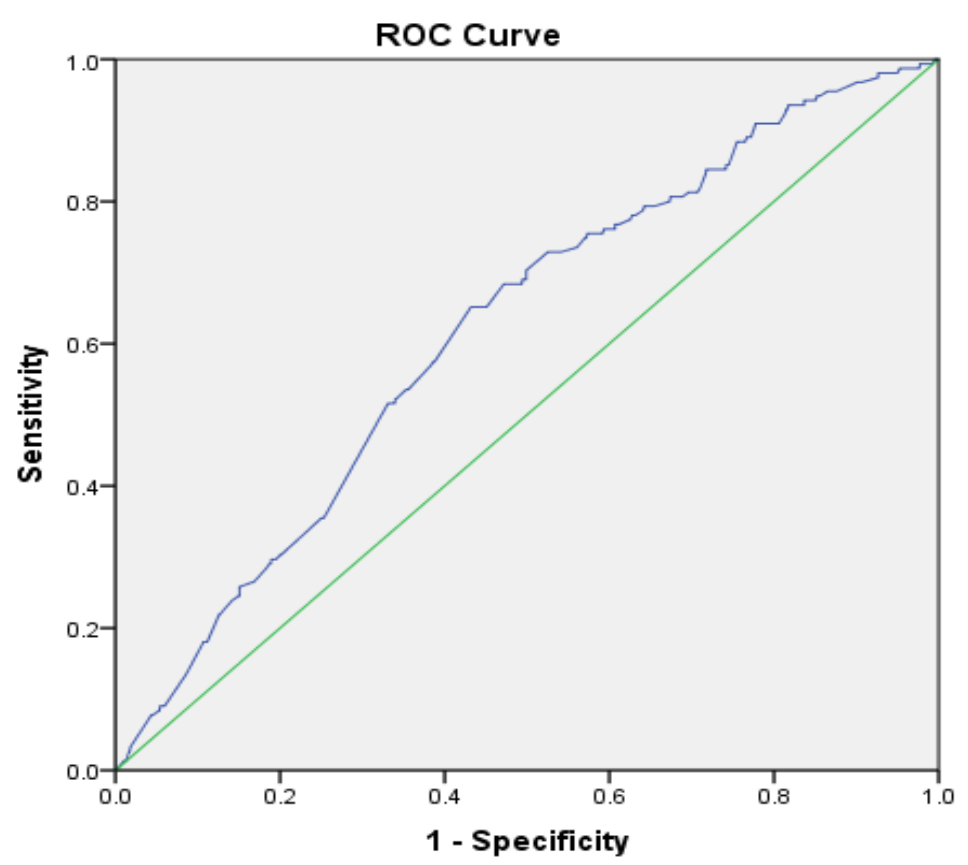

Diagonal segments are produced by ties.

Figure 1. Receiver operator characteristic (ROC) curve 
Table 4. Prevalence of CPDI by socioeconomic and demographic characteristics

\begin{tabular}{|c|c|c|c|c|}
\hline & $\begin{array}{c}\text { Normal or no distress } \\
\mathrm{n}(\%)\end{array}$ & $\begin{array}{l}\text { Mild to moderate distress } \\
\mathrm{n}(\%)\end{array}$ & $\begin{array}{c}\text { Severe distress } \\
\mathrm{n}(\%)\end{array}$ & $\chi^{2} ; \mathrm{p}$-value \\
\hline \multicolumn{5}{|l|}{ Age } \\
\hline$<30$ & $337(60.50)$ & $195(35.0)$ & $25(4.5)$ & \\
\hline $31-45$ & $326(62.2)$ & $190(36.3)$ & $8(1.5)$ & \\
\hline 46 and above & $135(76.7)$ & $39(22.2)$ & $2(1.1)$ & $24.5 ;<0.001$ \\
\hline \multicolumn{5}{|l|}{ Gender } \\
\hline Female & $500(62.1)$ & $284(35.3)$ & $21(2.6)$ & \\
\hline Male & $298(65.9)$ & $140(31.0)$ & $14(3.1)$ & $2.50 ; 0.286$ \\
\hline \multicolumn{5}{|l|}{ Religion } \\
\hline Islam & $713(63.5)$ & $378(33.7)$ & $31(2.8)$ & \\
\hline Non-Islam & $85(63.0)$ & $46(34.1)$ & $4(3.0)$ & $0.029 ; 0.986$ \\
\hline \multicolumn{5}{|l|}{ Education } \\
\hline Primary & $69(72.6)$ & $23(24.2)$ & $3(3.2)$ & \\
\hline Secondary & $610(61.8)$ & $347(35.2)$ & $30(3.0)$ & \\
\hline Tertiary & $119(68.0)$ & $54(30.9)$ & $2(1.1)$ & $7.80 ; 0.099$ \\
\hline \multicolumn{5}{|l|}{ Occupation } \\
\hline Employed & $540(64.5)$ & $274(32.7)$ & $23(2.7)$ & \\
\hline Unemployed & $92(60.9)$ & $56(37.1)$ & $3(2.0)$ & \\
\hline Student & $166(61.7)$ & $94(34.9)$ & $9(3.3)$ & $1.95 ; 0.745$ \\
\hline \multicolumn{5}{|l|}{ Monthly family income } \\
\hline < IDR 1,700,000,- & $193(62.5)$ & $106(34.3)$ & $10(3.2)$ & \\
\hline IDR $1,700,000$-IDR $4,500,000$ & $220(62.7)$ & $122(34.8)$ & $9(2.6)$ & \\
\hline$>$ IDR 4,500,000,- & $385(64.5)$ & $196(32.8)$ & $16(2.7)$ & $0.776 ; 0.942$ \\
\hline \multicolumn{5}{|l|}{ Health worker } \\
\hline Yes & $123(65.1)$ & $63(33.3)$ & $3(1.6)$ & \\
\hline No & $675(63.2)$ & $361(33.8)$ & $32(3.0)$ & $1.24 ; 0.537$ \\
\hline Residence & $641(62.7)$ & $351(34.3)$ & $30(2.9)$ & \\
\hline Java Island & $157(66.8)$ & $73(31.1)$ & $5(2.1)$ & $1.56 ; 0.458$ \\
\hline \multicolumn{5}{|l|}{ Outside Java Island } \\
\hline Total & $798(63.5)$ & $424(33.7)$ & $35(2.8)$ & \\
\hline
\end{tabular}

Table 5. Internal consistency

\begin{tabular}{cccrr}
\hline Area & Std. Error & Asymptotic sig. & \multicolumn{2}{c}{$\begin{array}{c}\text { Asymptotic 95\% confidence interval } \\
\text { Lower bound }\end{array}$} \\
& & & Upper bound \\
\hline 0.619 & 0.023 & 0.000 & 0.574 & 0.664 \\
\hline
\end{tabular}

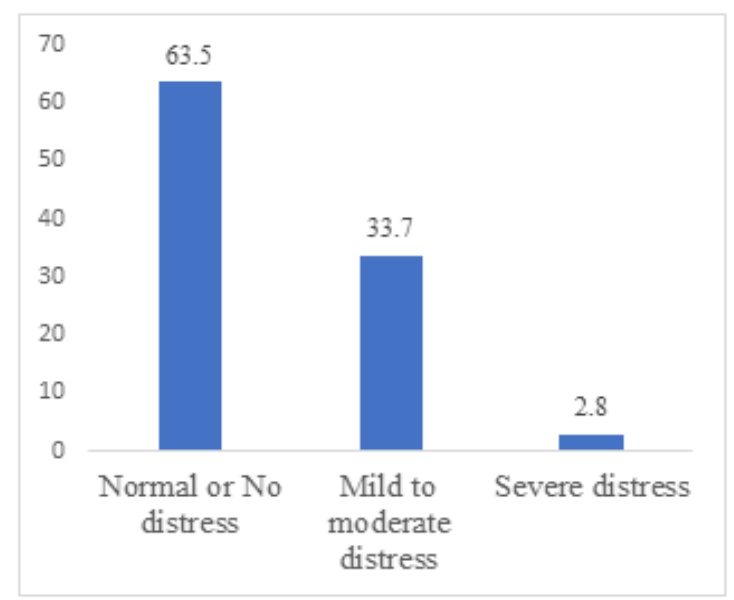

Figure 2. Prevalence of psychological distress during COVID-19 in Indonesia

The number of healthcare workers responses in this study was $186(15 \%)$, and $3(1.6 \%)$ already showed severe distress. With the task of directly engaged in the diagnosis, treatment, and care for patients with COVID-19, healthcare workers, become one of the vulnerable groups that need protection from physical and mental health [12]. Since Indonesia showed an increase in COVID-19 cases, it is paramount to ensure that healthcare workers are adequately protected. This study showed that respondents with income more than IDR 4,500,00 have more severe distress (16\%) than those with less than IDR 4,500,00. Factors contributed to 
this number might correlate with the level of education. Generally, people with less income also had lower education. The task of educating the general population becomes more important to ensure they followed health protocol correctly. Lesson from another study stated that clear and updated information is essential $[3,9,28]$. Age is the only variable associated significantly with distress in this study. Less than 30 years of age, respondents were having severe distress more compared to the older group. The result contradicted with the findings that COVID-19 infected more on older people rather than young ones. We did not investigate the information sources used by respondents. However, as in another study, it should be considered that the lockdown has given respondents to watch television and surf the web with more time in hand [18]. At present, the young age group seems to have more information derived from social media and the internet. That is why the government must provide clear and valid information for them using the sources familiar to this age group. As mentioned before, good and timely information is essential.

The mental health issue regarding the COVID-19 pandemic needs consideration on multiple levels. It is not only for vulnerable groups such as older age groups, women, and healthcare workers but also for the general population. The community needs to understand the magnitude of the problem during the COVID-19 pandemic to ensure they followed every health protocol assigned. However, although health protocols, safety measures, and other programs for the prevention of COVID-19 were already available, they would not be effective without other stakeholders' collaboration [14, 15, 17]. The prevention of mental health during the pandemic is not only government responsibilities but also communities, including private sectors and other organizations. The study limitations are including the limited representation of the respondents. In this study, data collected using the online form that people can access only by those having internet facilities, which represent higher economic status. The result is not representative of the status of mental health for the population in general. The samples also showed a higher female responder (64\%), similar to another study, which might also reflect the different results if the samples are more balanced between females and males [18]. Respondents from Java island comprise more than $81 \%$, which might show the differences in the internet's infrastructure, thus the differences in the information received. The results can be used to tailor the media for communication and information for the population in outer Java Island. Since this study has several limitations on representativeness, further study needs to understand the mental health status. Nevertheless, this study can still be used as a preliminary result in developing programs targeted for better mental health resilience during the pandemic.

\section{CONCLUSION}

During the early break of the COVID-19 pandemic, more than forty percent of respondents rated their psychological state having moderate to severe distress. Age was the only variable significantly related to a higher degree of distress. Although the study is not representative of the mental health of the whole population, the findings can be used to develop better psychological intervention measures and the prevention of mental health through education.

\section{REFERENCES}

[1] Worldodometers, Worldodometer, 2020. [Online]. Available from: https://www.worldometers.info/coronavirus/

[2] WHO, "National Implementation Measures for the International Health Regulations 2005 (IHR) COVID-19 as a Public Health Emergency of International Concern PHEIC) under the IHR protect against, control an,” vol. 2005. 2020.

[3] Alan F., Vivien S., Sven S., The coronavirus effect on global economic sentiment, McKinsey, 2020. [Online]. Available: https://www.mckinsey.com/business-functions/strategy-and-corporate-finance/our-insights/thecoronavirus-effect-on-global-economic-sentiment

[4] Yehuda Pollak, Haym Dayan, Rachel Shoham, Itai Berger, "Predictors of non-adherence to public health instructions during the COVID-19 pandemic," Psychiatry Clin Neurosci., 2020.

[5] Shahid Z., Kalayanamitra R., McClafferty B., Kepko D., Ramgobin D., Patel R., et al.. "COVID-19 and Older Adults: What We Know," J Am Geriatr Soc., vol. 68, no. 5, pp. 926-9, 2020.

[6] Wang C., Pan R., Wan X., Tan Y., Xu L., Ho CS, et al., "Immediate psychological responses and associated factors during the initial stage of the 2019 coronavirus disease (COVID-19) epidemic among the general population in China," International Journal of Environmental Research and Public Health, vol. 17, no. 5, p. 1729, 2020.

[7] Lai J., Ma S., Wang Y., Cai Z., Hu J., Wei N., et al., "Factors Associated With Mental Health Outcomes Among Health Care Workers Exposed to Coronavirus Disease 2019," JAMA Netw Open., vol. 3, no. 3, p. e203976, 2020.

[8] Alenazi TH, Bindhim NF, Alenazi MH, Tamim H, Althumiri NA, Alqahtani SA., "Prevalence and predictors of anxiety among healthcare workers in Saudi Arabia during the COVID-19 pandemic," J Infect Public Health, 2020, doi: https://doi.org/10.1016/j.jiph.2020.09.001.

[9] Chu DK, Akl EA, Duda S., Solo K., Yaacoub S., Schünemann HJ., "Physical distancing, face masks, and eye protection to prevent person-to-person transmission of SARS-CoV-2 and COVID-19: a systematic review and meta-analysis," The Lancet, vol. 395, no. January, pp. 9-21, 2020. 
[10] Musa HH, Musa TH, Musa IH, Oderinde O., "Letter to Editor COVID-19 outbreak and medical waste : Challenge in hand," International Joutnal of Public Health Science (IJPHS), vol. 9, no. 3, pp. 153-4, 2020.

[11] Mazza C., Ricci E., Biondi S., Colasanti M., Ferracuti S., Napoli C., et al., "A nationwide survey of psychological distress among italian people during the COVID-19 pandemic: Immediate psychological responses and associated factors," Int J Environ Res Public Health., vol. 17, no. 9, pp. 1-14, 2020.

[12] Yamamoto T., Uchiumi C., Suzuki N., Yoshimoto J., Murillo-Rodriguez E., The psychological impact of "mild lockdown in Japan during the COVID-19 pandemic: a nationwide survey under a declared state of emergency, 2020. [Online]. Available: http://medrxiv.org/content/early/2020/07/17/2020.07.17.20156125.abstract

[13] WHO., Mental Health and Psychosocial Considerations During COVID-19 Outbreak. World Health Organization. 2020.

[14] Tarlton D., Addressing Mental Health During COVID-19, 2020. [Online]. Available: https://www.undp.org/content/undp/en/home/blog/2020/addressing-mental-health-during-COVID-19.html

[15] Sailesh S., Goothy K., Goothy S., Chakraborty H., "COVID-19 lockdown impact on the mental health of students : need to start a mental health cell," MOJ Anat Physiol., vol. 7, no. 2, pp. 51-2, 2020.

[16] Pierce M., Hope H., Ford T., Hatch S., Hotopf M., John A., et al., "Mental health before and during the COVID-19 pandemic: a longitudinal probability sample survey of the UK population," The Lancet Psychiatry, vol. 7, no. 10, pp. 883-892, 2020.

[17] Kemenkes RI., "Guidelines for Mental Health and Psychosocial Support in the COVID-19 Pandemic/Pedoman Dukungan Kesehatan Jiwa dan Psikososial pada Pandemi COVID-19," 2020.

[18] Kemenkes RI., Guidelines for community empowerment in disaster management and health crises during the COVID-19 period/Pedoman pemberdayaan masyarakat dalam penanggulangan bencana dan krisis kesehatan pada masa COVID-19, 2020.

[19] Kemenkes RI, "Decree of the minister of health of the republic of Indonesia number hk.01.07/menkes/328/2020 regarding guidelines for the prevention and control of COVID-19/Keputusan menteri kesehatan republik indonesia nomor hk.01.07/menkes/328/2020 tentang panduan pencegahan dan pengendalian COVID-19, vol. 1. 2020.

[20] Kemenkes RI, "Guidelines for the Prevention and Control of Coronavirus Disease COVID-19/Pedoman Pencegahan dan Pengendalian Coronavirus Disease (COVID-19)," vol. 4, p. 1-214, 2020

[21] Gallè F., Sabella EA, Da Molin G., De Giglio O., Caggiano G., Di Onofrio V., et al., "Understanding knowledge and behaviors related to COVID-19 epidemic in italian undergraduate students: The epico study," Int J Environ Res Public Health., vol. 17, no. 10, pp. 1-11, 2020.

[22] Figueiredo AM De, Codina AD, Marculino D figueirredo, M S, A Leon C., "Impact of lockdown on COVID-19 incidence and mortality in China: an interrupted time series study," Bull World Heal Organ, 2020. [Online]. Available: http://dx.doi.org/10.2471/BLT.20.256701

[23] Kazmi SSH, Hasan K., Talib S., Saxena S., "COVID-19 and Lockdwon: A Study on the Impact on Mental Health," SSRN Electron J., 2020

[24] Király O., Potenza MN, Stein DJ, King DL, Hodgins DC, Saunders JB, et al., "Preventing problematic internet use during the COVID-19 pandemic: Consensus guidance," Compr Psychiatry., vol. 100, p. 1-4, 2020.

[25] Bhat BA, Khan S., Manzoor S., Niyaz A., Tak HJ, Anees S-U-M, et al., "A Study on Impact of COVID-19 Lockdown on Psychological Health, Economy and Social Life of People in Kashmir," Int J Sci Healthc Res., vol. 5, no. 2 , p. $37,2020$.

[26] Faidah NC, Respati T, Fitriyana S., "Student Perception of State Senior High School in Bandung through and Individual that owned Mental Health Disorder," Pros Pendidik Dr., vol. 3, no. 1, pp. 215-221, 2017.

[27] Lam LT., "Mental health literacy and mental health status in adolescents: A population-based survey," Child Adolesc Psychiatry Ment Health, vol. 8, no. 1, pp. 1-8, 2014.

[28] Paludan-Müller AS, Boesen K., Klerings I., Jørgensen KJ, Munkholm K., Hand cleaning with ash for reducing the spread of viral and bacterial infections: a rapid review, 2020. [Online]. Available: https://www.healthevidence.org/view-article.aspx?a=hand-cleaning-ash-reducing-spread-viral-bacterial-infectionsrapid-review-38436

[29] Atalan A., "Is the lockdown important to prevent the COVID-9 pandemic? Effects on psychology, environment and economy-perspective," Ann Med Surg., vol. 56, pp. 38-42, 2020, doi: https://doi.org/10.1016/j.amsu.2020.06.010.

[30] Rosen S., "As COVID-19 crisis continues, other infectious diseases threaten," LabPulse.com. 2020.

[31] Baraniuk C., "COVID-19: People are gathering again, but can crowds be made safe?" BMJ, vol. 371, p. m3511, 2020, doi: https://doi.org/10.1136/bmj.m3511. 